ISSN 0103-8478

\title{
Genetically modified corn on fall armyworm and earwig populations under field conditions
}

\author{
Milho geneticamente modificado e sua ação sobre a \\ lagarta-do-cartucho e tesourinha em condições de campo
}

\author{
Marina Regina Frizzas ${ }^{\mathrm{I}}$ Sinval Silveira Neto ${ }^{\mathrm{II}}$ \\ Charles Martins de Oliveira ${ }^{\mathrm{III}}$ Celso Omoto ${ }^{\mathrm{II}}$
}

\section{ABSTRACT}

The effects of corn MON810 on the Spodoptera frugiperda (J.E. Smith) and the earwig Doru luteipes (Scudder) were tested under field conditions in Brazil. Results from MON810 corn fields were compared with those fields of conventional corn with and without the application of insecticides in four harvests in the region of Barretos, SP. It was assessed the damage to $S$. frugiperda via direct counts of the number of fall armyworms and adults and nymphs of the predator $\boldsymbol{D}$. luteipes on corn plants. The rate of $\boldsymbol{S}$. frugiperda damage and the average numbers of larvae (large and small) were lower in the MON810 corn field relative to the control plot. There were no differences $(P>0.05)$ between treatments regarding the predator abundance in corn plants. The second crop season ("safrinha") showed the greatest extent of $\boldsymbol{S}$. frugiperda damage and the lowest average abundance of earwigs. MON810 was effective in controlling S. frugiperda and abundance of predator $\boldsymbol{D}$. luteipes was similar in the three treatments under field conditions.

Key words: Spodoptera frugiperda, MON810, Doru luteipes, transgenic plant.

RESUMO

Avaliou-se o efeito do milho geneticamente modificado MON810 sobre o inseto praga Spodoptera frugiperda (J.E. Smith) e o seu predador Doru luteipes (Scudder) em condições de campo no Brasil. As avaliações foram conduzidas em campos de milho MON810, comparadas com milho convencional com e sem aplicação de inseticidas, em quatro safras na região de Barretos, SP. Foram avaliados os danos de S. frugiperda em plantas e a contagem do número de lagartas de $\boldsymbol{S}$. frugiperda $e$ de adultos e ninfas do predador $\boldsymbol{D}$. luteipes em plantas de milho. Verificou-se uma menor porcentagem de danos de $\boldsymbol{S}$. frugiperda $e$ os menores números médios de lagartas (pequenas e grandes) no milho MON810. Não foram observadas diferenças $(P>0,05)$ entre os tratamentos na abundância do predador $\boldsymbol{D}$. luteipes em plantas de milho. A segunda época de plantio apresentou as maiores porcentagens de danos de $\boldsymbol{S}$. frugiperda e as menores médias do número de tesourinhas coletadas. O milho MON810 foi efetivo no controle de $\boldsymbol{S}$. frugiperda e a abundância do predador $\boldsymbol{D}$. luteipes foi similar nos três tratamentos, em condições de campo.

Palavras-chave: Spodoptera frugiperda, MON810, Doru luteipes, planta transgênica.

\section{INTRODUCTION}

Brazil ranks second among all countries in the amount of area planted with transgenic crops (JAMES, 2012). The genetically modified corn MON810, which expresses the CrylAb protein of Bacillus thuringiensis Berliner, was approved for commercial release in Brazil in 2007 (CTNBio, 2011). Surveys have indicated that over $80 \%$ of the agricultural area planted with corn in Brazil consists of transgenic hybrids (CELERES, 2012). The possible adverse effects of this technology on several levels of insect communities have been questioned; specifically, there has been uncertainty regarding the possibility of transgenic plants affecting non-target organisms in different trophic levels (LÖVEI \& ARPAIA, 2005).

One of the target pests of MON810 corn in Brazil is the fall armyworm, Spodoptera frugiperda

'Departamento de Zoologia, Instituto de Ciências Biológicas, Universidade de Brasília (UnB), Campus Darcy Ribeiro, 70910-900, Brasília, DF, Brasil. E-mail: frizzas@unb.br. Autor para correspondência.

IIDepartamento de Entomologia e Acarologia, Escola Superior de Agricultura Luiz de Queiroz (ESALQ), Universidade de São Paulo (USP), Piracicaba, SP, Brasil.

IIIEmbrapa Cerrados, Planaltina, DF, Brasil. 
(J.E. Smith) (Lepidoptera: Noctuidae), which is considered to be one of the most serious agricultural pests in many different crops. Various studies have suggested that the use of genetically modified corn results in reduced applications of insecticides, in particular, broad-spectrum insecticides, thereby improving the maintenance of natural enemies (GOULD, 1998) that help control pests and slow the evolution of resistance (MASCARENHAS \& LUTTRELL, 1997).

Bt-based bioinsecticides have not been effective in controlling $\boldsymbol{S}$. frugiperda, and certain studies have suggested that this species has a lower susceptibility to Cry1 $\mathrm{Ab}$ proteins relative to other pests (LUTTRELL et al., 1999). However, transgenic corn with the $B t$ gene has been shown to be effective in controlling this species under field conditions (LYNCH et al., 1999; BUNTIN et al., 2001), thereby suggesting that other factors may contribute to the control of $\boldsymbol{S}$. frugiperda, such as the effects of natural enemies. In Brazil, Doru luteipes (Scudder) (Dermaptera: Forficulidae) has proven to be a promising agent for the biological control of corn pests, in particular S. frugiperda (REIS et al., 1988).

The objective of this study was to evaluate the effect of the genetically modified corn MON810 on $\boldsymbol{S}$. frugiperda and its predator $\boldsymbol{D}$. luteipes under field conditions in Brazil.

\section{MATERIALS AND METHODS}

The study was performed in field during the years 1999, 2000 and 2001 in four corn harvests: the first planting season of $1999 / 2000$ (planted at 16 Dec. 1999), the second planting season of 2000 (25 Mar. 2000), the winter/spring planting of 2000 (13 Sep. 2000) and the second planting season of 2001 (15 Mar. 2001) at Barretos, SP, Brazil (20³3'26"S, 48.34'04"W and $530 \mathrm{~m}$ elevation). The experiment installation was completed in accordance with the biosafety standards recommended by the National Technical Commission on Biosafety (Comissão Técnica Nacional de Biossegurança - CTNBio).

The event of genetically modified corn used in this study was MON810 (Monsanto do Brasil Ltd.), which expresses the Cry1Ab protein of B. thuringiensis. For comparison, the conventional hybrid corn varieties DKB 806 (first planting season 1999/2000) and DKB 909 (the remaining harvests) were used. These commercial hybrids were the most planted in Brazil between 1999 and 2001 and did not represent isolines of MON810.
The following treatments were evaluated: genetically modified corn MON810 (MON), conventional corn without insecticide application (CWI) and conventional corn with insecticide application (CIN). An area of 0.5 ha was used for each treatment. All cultivation practices, except for the insecticide application, were similar in the three treatments and followed the agronomic recommendations established for the region. In the CIN treatment, the insecticide lufenuron was applied at a dose of $15 \mathrm{~g} \mathrm{AI} \mathrm{ha}^{-1}$ when the threshold level for S. frugiperda control was reached $(20 \%$ of plants exhibiting leaf damages).

To evaluate $\boldsymbol{S}$. frugiperda and $\boldsymbol{D}$. luteipes, eight replicates of ten plants and/or corn ears per replicate were examined. The corn plants were collected, transported to the laboratory and the number of $\boldsymbol{S}$. frugiperda and $\boldsymbol{D}$. luteipes present in all parts of the plant were recorded. The evaluation of $\boldsymbol{S}$. frugiperda damage was initiated approximately seven days after the emergence of the plants, and six evaluations were performed every four to five days. It was recorded the percentages of plants that were damaged by $S$. frugiperda. An evaluation of the number of $\boldsymbol{S}$. frugiperda larvae was performed on four dates (with the exception of the winter/spring crop season of 2000) by recording the number of small larvae $(\leq 1.5 \mathrm{~cm})$ and large larvae $(>1.5 \mathrm{~cm})$. For D. luteipes, six evaluations were completed to register the number of earwigs (adults and nymphs).

In the analysis of quantitative variables, due to the lack of normality shown by the data, a necessary condition for the use of analysis of variance (ANOVA), it was opted to apply the WilcoxonMann-Whitney U test (SAS INSTITUTE, 2001). This non-parametric statistical procedure may be used for comparison of two independent samples for continuous scale variables. Thus, for each evaluation date within each corn harvests, the treatments MON, CWI and CIN were compared two by two, adopted a significance level of 0.05 .

\section{RESULTS AND DISCUSSION}

The genetically modified corn MON810 showed the lowest percentage of $S$. frugiperda damage in the four harvest seasons that were evaluated (Figure 1), and fewer small and large larvae of this pest were found relative to the control (CWI). However, no difference $(\mathrm{P}>0.05)$ in the number of small and large larvae was detected between MON and CIN treatments in most of date sampled (Figure 2). 

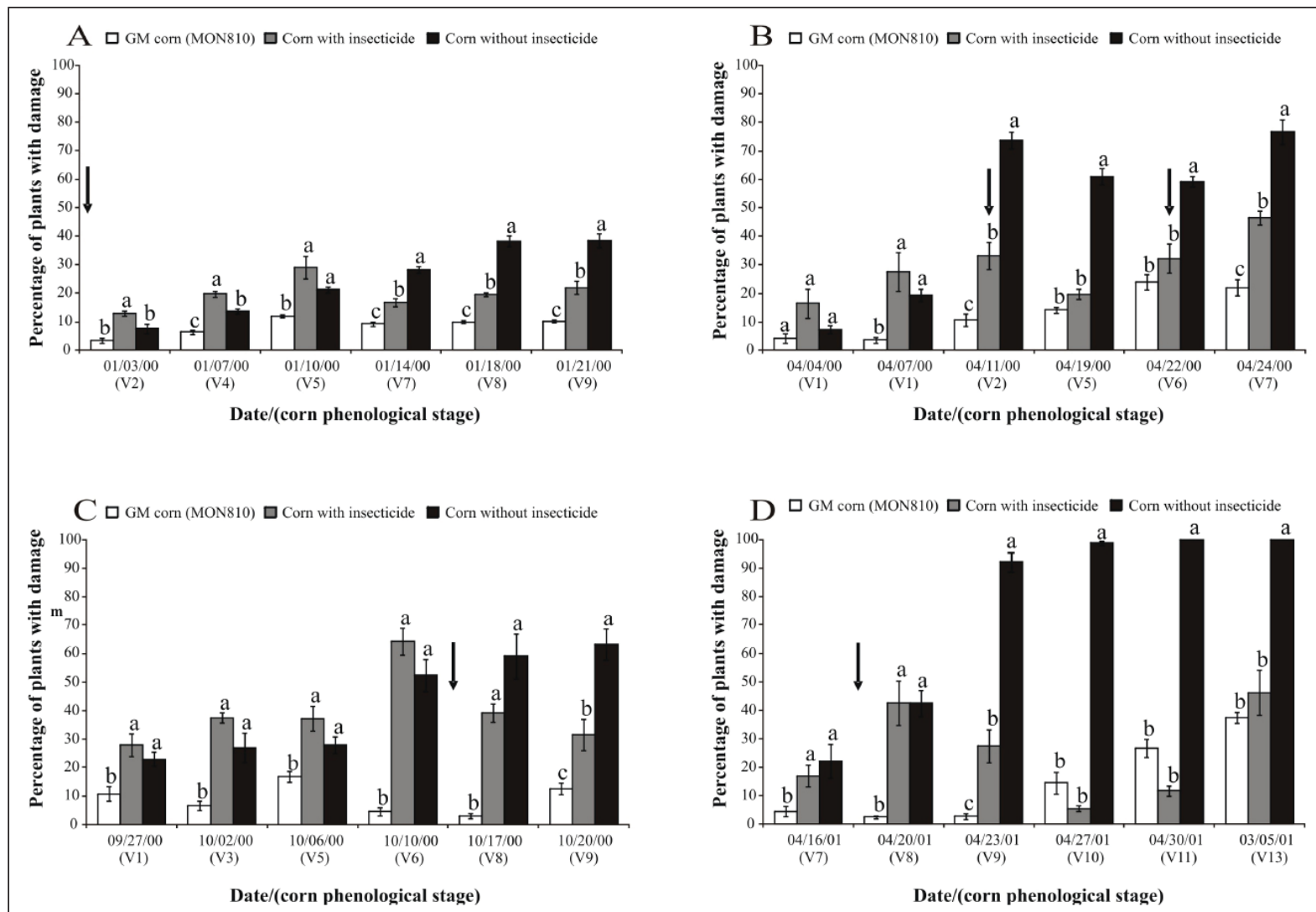

Figure 1 - Mean percentage of plants damaged by Spodoptera frugiperda for the treatments: genetically modified corn MON810 (MON), conventional corn without insecticide application (CWI) and conventional corn with insecticide application (CIN), in Barretos, SP. A) First planting season of 1999/2000, B) second planting season of 2000, C) winter/spring planting season of 2000 and D) second planting season of 2001. Arrows indicate date of insecticide application in the CIN treatment. Bars followed by the same letter for each evaluation date are not statistically different according to Wilcoxon-Mann-Whitney $\mathrm{U}$ tests $(\mathrm{P}<0.05)$. Text in parenthesis on the $\mathrm{X}$ axis represents the corn phenological stage: $\mathrm{V}$-vegetative $(1 \ldots \mathrm{n}=$ number of leaves $-\mathrm{VT}=$ tassel completely visible $)$ and $\mathrm{R}$ - reproductive.

Differences $\quad(\mathrm{P}<0.05)$ were observed between treatments for the four corn harvests with respect to the percentage of plants with $\boldsymbol{S}$. frugiperda damage. For almost all dates and harvest seasons, the MON treatment had the lowest percentage of plants with damage (Figure 1). All treatments confirmed that the extent of $\boldsymbol{S}$. frugiperda damage was highest during the second corn crop season (Figure 1). This level of damage probably occurred because the observed abundance of the predator $\boldsymbol{D}$. luteipes was lower in the second planting season relative to the first planting season and the winter/spring crop (Figure 3). Previous studies have demonstrated the potential of $\boldsymbol{D}$. luteipes, both in the nymph and adult stages, to control $\boldsymbol{S}$. frugiperda populations (REIS et al., 1988; GUERREIRO et al., 2003). On average, $\boldsymbol{D}$. luteipes nymphs consume 13 eggs and 12 first instar larvae of $\boldsymbol{S}$. frugiperda each day, and adults consume 21 larvae per day (REIS et al., 1988). The presence of D. Iuteipes was very often associated to the presence of egg masses and small larvae of $\boldsymbol{S}$. frugiperda, with negative correlation in the number of these two species in cornfields (GUERREIRO et al., 2003). Therefore, a reduction in the predator population can lead to an increase in the pest population. Moreover, in regions in which corn is grown throughout the year, as in Barretos, SP, pest populations remain high, thereby hindering their control. This consistently high population can lead to an increase in the number of insecticide spraying events, as observed for the second planting season of 2000 (two applications), and can accelerate the evolution of pest resistance to the insecticides that are used (YU, 1991).

It was observed that, in general, the CWI treatment had the highest average numbers of large and small S. frugiperda larvae (Figure 2). In all cropping events, the presence of small larvae of $\boldsymbol{S}$. frugiperda in MON810 corn was observed. However, the number of large larvae was generally lower in the MON treatment than in the CWI treatment (Figure 2). 


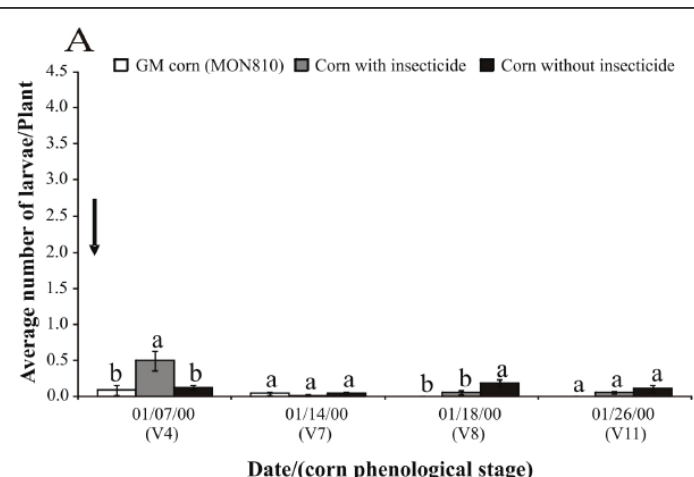

$\mathrm{C}$
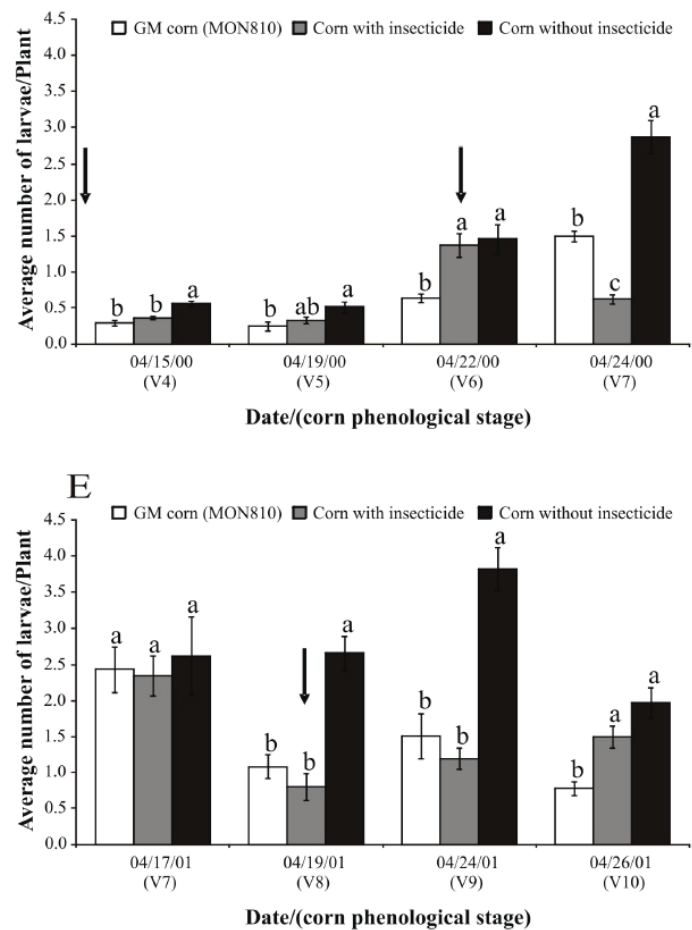

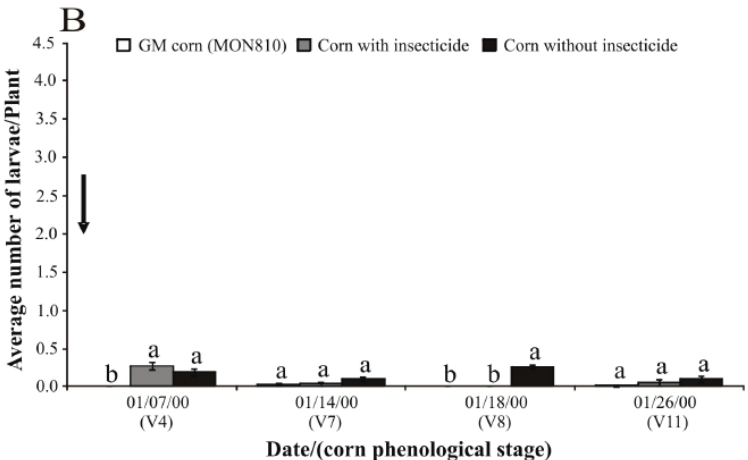

$\mathrm{D}$
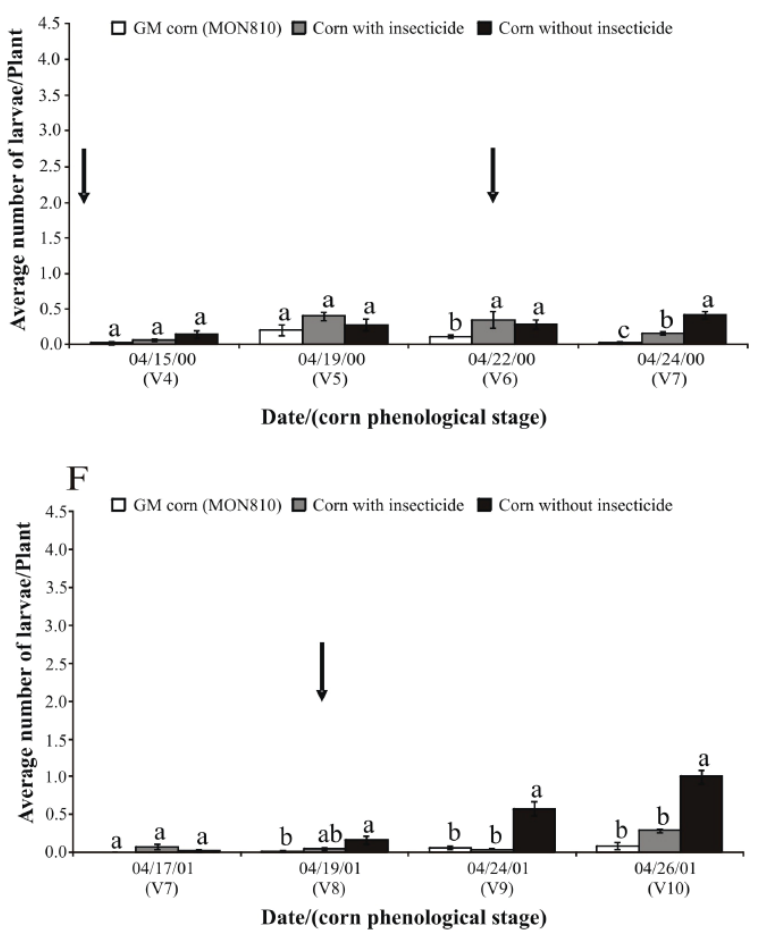

Figure 2 - Mean number of small and large Spodoptera frugiperda larvae for the treatments: genetically modified corn MON810 (MON), conventional corn without insecticide application (CWI) and conventional corn with insecticide application (CIN), in Barretos, SP. First planting season of 1999/2000: A) small and B) large larvae. Second planting season of 2000: C) small and D) large larvae. Second planting season of 2001: E) small and F) large larvae. Arrows indicate date of insecticide application in the CIN treatment. Bars followed by the same letter for each evaluation date are not statistically different according to Wilcoxon-MannWhitney $U$ tests $(\mathrm{P}<0.05)$. Text in parenthesis on the $\mathrm{X}$ axis represents the corn phenological stage: $\mathrm{V}$-vegetative $(1 \ldots \mathrm{n}=$ number of leaves $-\mathrm{VT}=$ tassel completely visible) and $\mathrm{R}$ - reproductive.

This result is indicative of the efficient control of lepidopteron pests because the $\boldsymbol{S}$. frugiperda larvae probably died before they could cause severe damage to the plants. A similar mechanism for controlling $S$. frugiperda was observed for the genetically modified corn MON810 (BUNTIN et al., 2001) and other varieties containing the $\mathrm{Bt}$ protein (WILLIAMS et al., 1997; LYNCH et al., 1999). The Cry1Ab protein is continuously expressed in the leaves of MON810 corn during the entire crop development (WILLIAMS et al., 1997), thereby allowing for the larval control throughout the crop cycle.

Bt-based bioinsecticides have not shown good results in controlling $S$. frugiperda. In bioassays performed in the laboratory, only a reduction in the growth of the pest has been observed (WILLIAMS et al., 1997; 1998; MENDES et al., 2011), and certain studies suggest that $S$. frugiperda is a species with lower susceptibility to the Cry1 Ab protein (LUTTRELL et al., 1999). In addition, the 


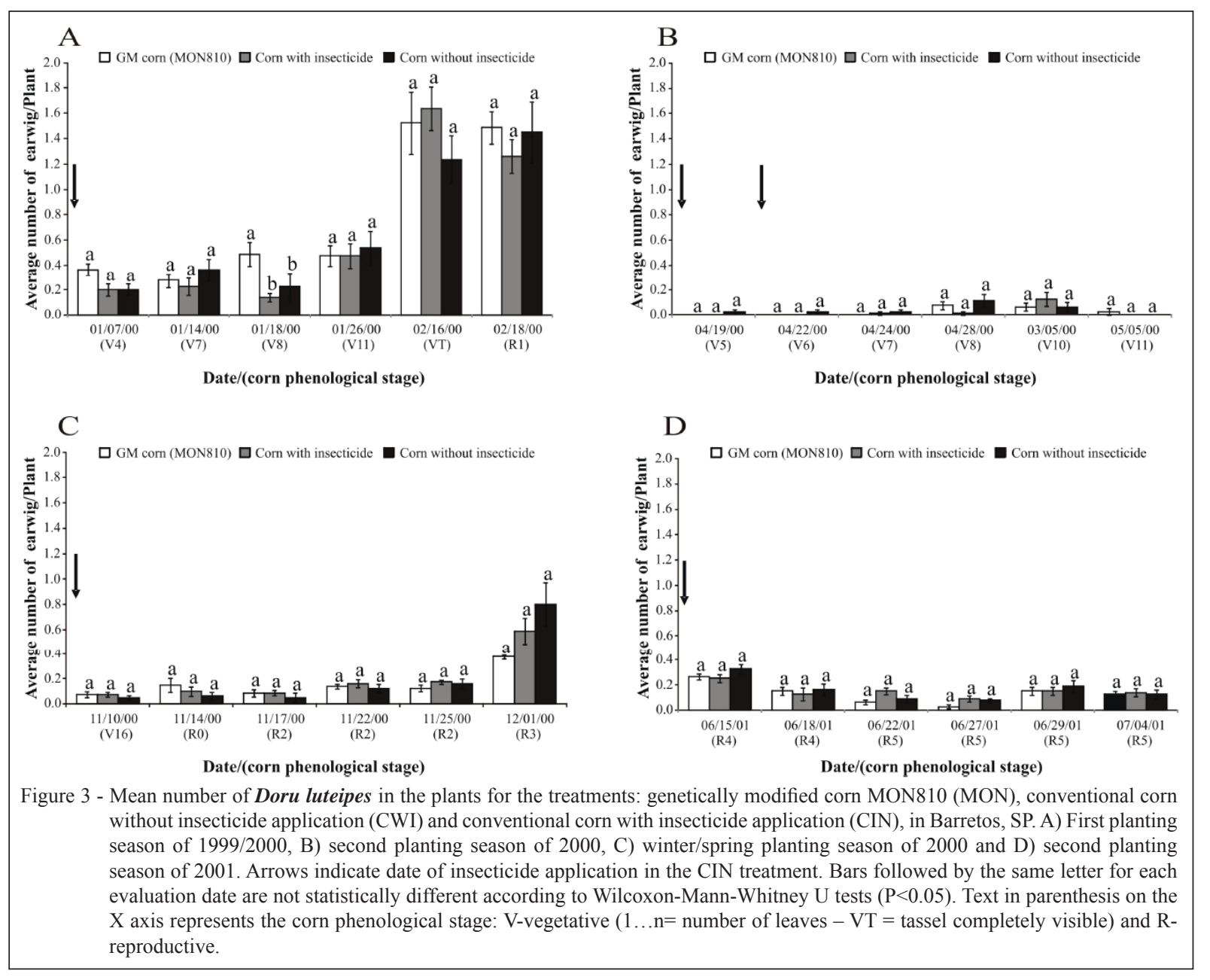

selection of surviving insects in bioassays showed an increased level of tolerance to the Cry1 Ab protein of $\mathrm{Bt}$ in populations of the fall armyworm after four generations, thereby indicating that tolerance is an inherited trait (VILELLA et al., 2002). Despite these facts, Bt transgenic corn has been shown to be effective in controlling this species under field conditions (LYNCH et al., 1999; BUNTIN et al., 2001). However, the extent of control can vary depending on the hybrid corn that is used (ARCHER et al., 2000).

Based on the average number of earwigs collected from the corn plants, observed that the abundance of $\boldsymbol{D}$. luteipes was similar for all treatments in four seasons, suggesting that MON810 does not affected the dynamics of the predator in the short term (Figure 3). No effect of Bt corn expressing Cry1 Ab on D. luteipes population was also reported under field conditions in Brazil by FERNANDES et al. (2007). It is possible that the populations of $\boldsymbol{D}$. luteipes found sufficient amounts of available food in the MON810 corn throughout the crop cycle (i.e., eggs, neonate and small larvae of $\boldsymbol{S}$. frugiperda). In general, the proteins of $\boldsymbol{B}$. thuringiensis are expressed at high levels in plant tissues; depending on the promoter that is used, these proteins can also be expressed in pollen, seeds and roots (KOZIEL et al., 1993). Thus, insect predators, which are important natural control agents, may be affected by feeding on the pollen of genetically modified plants. Predators can also be affected when fed with prey that consumed the sap of transgenic plants due to the direct effects of the protein on the predator and to reduction in the nutritional quality of the prey (SCHULER et al., 1999). Moreover, transgenic plants may differentially affect specialist and generalist predators (RIDDICK et al., 1998); for example, generalists may feed on alternative prey and thereby continue to contribute to pest control.

A lower average number of earwigs were observed in the second corn planting season compared with the first planting season in the three 
treatments. These warm and humid months favor insect development. In corn, the largest populations of $\boldsymbol{D}$. luteipes are generally observed in cropping events implemented during the warmer months of the year (FENOGLIO \& TRUMPER, 2007); a decline in the occurrence of all forms of insects occurs in months with milder temperatures, and low numbers of eggs, nymphs and adults are observed during May, Jun. and Aug. The large predator population in the warmer seasons may also be a result of higher incidences of $\boldsymbol{S}$. frugiperda in the warmer months of the year, although no relationship was found between D. luteipes population and climatic factors such as temperature and rainfall (GUERREIRO et al., 2003).

The largest abundances of earwigs were also found in the first planting season with a peak in the population in Feb. There were no differences $(\mathrm{P}>0.05)$ in the average numbers of earwigs even in locations where the insecticide was applied (Figure 3). This lack of effect on earwigs probably occurred because the insecticide used (lufenuron) is selective for natural enemies (CAMPOS et al., 2011). In addition, the predator is more tolerant to insecticides in adult than in the nymph stage, whereas $\boldsymbol{B}$. thuringiensis is selective for all stages of the predator. Therefore, given the importance of $\boldsymbol{D}$. luteipes as a biological control agent of $\boldsymbol{S}$. frugiperda and the selectivity of $\mathrm{Bt}$ to the predator, $\mathrm{Bt}$ corn may be a good strategy in programs of integrated pest management.

Although MON810 represents one of the first events of genetically modified corn to control insects released commercially in Brazil, the results presented here serve as a model for future studies with more recent events involving the effects on the target pest and non-target organisms.

\section{CONCLUSION}

The results suggest that the genetically modified corn MON810 is effective in controlling S. frugiperda larvae and that the population dynamics $\boldsymbol{D}$. luteipes is similar in MON810 and in the conventional corn under field conditions. Thus, MON810 can be used as an important alternative for the management of $S$. frugiperda.

\section{ACKNOWLEDGEMENTS}

The authors acknowledge the Brazilian Federal Agency for the Support and Evaluation of Graduate Education (Coordenação de Aperfeiçoamento de Pessoal de Nível Superior, CAPES) for the fellowship rewarded to the first author. The authors also thank the agronomists Aroldo Marochi, Daniel Camposilvan, Rubens Pícoli and Odnei Fernandes for their assistance in the field studies. Mention of trade names or commercial products in this publication is solely for the purpose of providing specific information and does not imply recommendation or endorsement by the authors.

\section{REFERENCES}

ARCHER, T.L. et al. Whorl and stalk damage by European and Southwestern corn borers to four events of Bacillus thuringiensis transgenic maize. Crop Protection, v.19, p.181-190, 2000. Available from: <http://www.sciencedirect.com/science/article/ pii/S026121949900927>. Accessed: Oct. 21, 2012. doi: 10.1016/ S0261-2194(99)00092-7.

BUNTIN, G.D. et al. Evaluation of Yieldgard transgenic resistance for control of fall armyworm and corn earworm (Lepidoptera: Noctuidae) on corn. Florida Entomologist, v.84, p.37-42, 2001. Available from: $<$ http://www.jstor.org/stable/3496660>. Accessed: Jun. 15, 2012.

CAMPOS, M.R. et al. Insecticide selectivity and behavioral response of the earwig Doru luteipes. Crop Protection, v.30, p.1535-1540, 2011. Available from: <http://www.sciencedirect. com/science/article/pii/S0261219411002699>. Accessed: Oct. 25, 2012. doi: 10.1016/j.cropro.2011.08.013.

CELERES. $2^{\circ}$ acompanhamento de adoção da biotecnologia agrícola para a safra 2011/12. 2012. Available from: <http:// www.celeres.com.br/1/RelBiotecBrasil_1103.pdf $>$. Accessed: Apr. 24, 2012.

COMISSÃO TÉCNICA NACIONAL DE BIOSSEGURANÇA (CTNBio). Liberação comercial de milho geneticamente modificado resistente a insetos evento MON810. Parecer Técnico $\mathrm{n}^{\circ}$ 1.100/2007. 2011. Available from: <http://www.ctnbio.gov.br/ index.php/content/view/14056.html>. Accessed: Nov. 28, 2011.

FENOGLIO, M.S.; TRUMPER, E.V. Influence of weather conditions and density of Doru luteipes (Dermaptera: Forficulidae) on Diatraea saccharalis (Lepidoptera: Crambidae) egg mortality. Environmental Entomology, v.36, p.1159-1165, 2007. Available from: <http://www.bioone.org/doi/full/10.1603/0046-225X\%2820 07\%2936\%5B1159\%3AIOWCAD\%5D2.0.CO\%3B2>. Accessed: Nov. 21, 2012. doi: 10.1603/0046-225X(2007)36[1159:IOWCAD ]2.0.CO;2.

FERNANDES, O.A. et al. Short-term assessment of Bt maize on non-target arthropods in Brazil. Scientia Agricola, v.64, p.249-255, 2007. Available from: <http://www.scielo.br/scielo. php?script $=$ sci arttext\&pid=S0103-90162007000300006\&lng=e n\&nrm=iso\&tlng=en>. Accessed: Nov. 21, 2012. doi: 10.1590/ S0103-90162007000300006.

GUERREIRO, J.C. et al. Seasonal occurrence of Doru luteipes in maize in São Paulo, Brazil. Manejo Integrado de Plagas y Agroecologia, v.70, p.46-49, 2003.

GOULD, F. Sustainability of transgenic insecticidal cultivars: integrating pest genetics and ecology. Annual Review of Entomology, v.43, p.701-726, 1998. Available from: <http:// www.annualreviews.org/doi/abs/10.1146/annurev.ento.43.1.701>. Accessed: Nov. 21, 2012. doi: 10.1146/annurev.ento.43.1.701.

JAMES, C. Global status of commercialized biotech/GM crops: 2012. 44.ed Ithaca, NY: ISAAA, 2012. 18p. 
KOZIEL, M.G. et al. Field performance of elite transgenic maize plants expressing an insecticidal protein derived from Bacillus thuringiensis. Nature Biotechnology, v.11, p.194-200, 1993. Available from: <http://www.nature.com/nbt/journal/v11/n2/abs/ nbt0293-194.html>. Accessed: Nov. 21, 2012. doi: 10.1038/ nbt0293-194.

LÖVEI, G.L.; ARPAIA, S. The impact of transgenic plants on natural enemies: a critical review of laboratory studies. Entomologia Experimentalis et Aplicatta, v.114, p.1-14, 2005. Available from: <http://onlinelibrary.wiley.com/doi/10.1111/ j.0013-8703.2005.00235.x/abstract>. Accessed: Nov. 21, 2012. doi: $10.1111 / \mathrm{j} .0013-8703.2005 .00235 . x$.

LUTTRELL, R.G. et al. Variation in susceptibility of noctuid (Lepidoptera) larvae attacking cotton and soybean to purified endotoxin proteins and commercial formulations of Bacillus thuringiensis. Journal of Economic Entomology, v.92, p.21-32, 1999.

LYNCH, R.E. et al. Evaluation of transgenic sweet corn hybrids expressing CryIA(b) toxin for resistance to corn earworm and fall armyworm (Lepidoptera: Noctuidae). Journal of Economic Entomology, v.92, p.246-252, 1999.

MASCARENHAS, V.J.; LUTTRELL, R.G. Combined effect of sublethal exposure to cotton expressing the endotoxin protein of Bacillus thuringiensis and natural enemies on survival of bollworm (Lepidoptera: Noctuidae) larvae. Environmental Entomology, v.26, p.939-945, 1997.

MENDES, S.M. et al. Fall armyworm responses to genetically modified maize expressing the toxin Cry $1 \mathrm{~A}(\mathrm{~b})$. Pesquisa Agropecuária Brasileira, v.46, p.239-244, 2011. Available from: <http://www.scielo.br/scielo.php?script=sci arttext\&pid=S0100-204X2011000300003\&lng=en\&nrm $=\overline{\mathrm{is}}$ o\&tlng=pt $>$. Accessed: Jul. 18, 2012. doi: 10.1590/S0100204X2011000300003.

REIS, L.L. et al. Biology and potential of Doru luteipes for the control of Spodoptera frugiperda. Pesquisa Agropecuária Brasileira, v.23, p.333-342, 1988.
RIDDICH, E.W. et al. Effect of a seed-mix deployment of Cry3Atransgenic and nontransgenic potato on the abundance of Lebia grandis (Coleoptera: Carabidae) and Coleomegilla maculate (Coleoptera: Coccinellidae). Annals of the Entomological Society of America, v.91, p.647-653, 1998.

SAS INSTITUTE. SAS/STAT user's guide: statistics. 5ed. Cary, NC, 2001. Version 8.02.

SCHULER, T.H. et al. Potential side effects of insect-resistant transgenic plants on arthropod natural enemies. Trends in Biotechnology, v.17, p.210-216, 1999. Available from: <http:// www.sciencedirect.com/science/article/pii/S0167779998012980>. Accessed: Oct. 21, 2012. doi: 10.1016/S0167-7799(98)01298-0.

VILELLA, F.M.F. et al. Selection of the fall armyworm, Spodoptera frugiperda (Smith) (Lepidoptera: Noctuidae) for survival on Cry1A(b) Bt toxin. Revista Brasileira de Milho e Sorgo, v.1, p.12-17, 2002.

WILLIAMS, W.P. et al. Transgenic corn evaluated for resistance to fall armyworm and Southwestern corn borer. Crop Science, v.37, p.957-962, 1997. Available from: <https://www.soils.org/ publications $/$ cs/abstracts/37/3/CS0370030957? access $=0$ \& view $=p$ df>. Accessed: Jul. 18, 2012. doi: 10.2135/cropsci1997.001118 3X003700030042x.

WILLIAMS, W.P. et al. Evaluation of transgenic corn for resistance to corn earworm (Lepidoptera: Noctuidae), fall armyworm (Lepidoptera: Noctuidae), and Southwestern corn borer (Lepidoptera: Crambidae) in a laboratory bioassay. Journal of Agricultural Entomology, v.15, p.105-112, 1998.

YU, S.J. Insecticide resistance in the fall armyworm, Spodoptera frugiperda (J.E. Smith). Pesticide Biochemistry and Physiology, v.39, p.84-91, 1991. Available from: <http://www.sciencedirect. com/science/article/pii/0048357591902169>. Accessed: Oct. 12, 2012. doi: 10.1016/0048-3575(91)90216-9. 